\title{
Can the empirical sciences contribute to the moral realism/anti-realism debate?
}

\author{
Thomas Pölzler ${ }^{1}$
}

Received: 23 May 2016 / Accepted: 8 May 2017 / Published online: 20 May 2017

(C) The Author(s) 2017. This article is an open access publication

\begin{abstract}
An increasing number of moral realists and anti-realists have recently attempted to support their views by appeal to science. Arguments of this kind (such as evolutionary debunking arguments or arguments from moral disagreement) are typically criticized on the object-level. In addition, however, one occasionally also comes across a more sweeping metatheoretical skepticism. Scientific contributions to the question of the existence of objective moral truths, it is claimed, are impossible in principle; most prominently, because (1) such arguments impermissibly derive normative from descriptive propositions, (2) such arguments beg the question against non-naturalist moral realism, (3) science cannot inform conceptual accounts of moral judgements, and (4) the conceptual is logically prior to the empirical. My main aim in this paper is to clarify and critically assess these four objections. Moreover, based on this assessment, I will formulate four general requirements that science-based arguments in favor of moral realism and anti-realism should meet. It will turn out that these arguments are limited in several ways, and that some existing arguments have been unsound. Yet it is still possible in principle for the empirical sciences to contribute to the moral realism/anti-realism debate.
\end{abstract}

Keywords Moral realism · Moral anti-realism · Moral psychology · Experimental philosophy $\cdot$ Metaethics

Moral realism and anti-realism have been understood in various different ways. On what is probably the most common definition they are about the existence of objective

\footnotetext{
Thomas Pölzler

thomas.poelzler@uni-graz.at

https://homepage.uni-graz.at/en/thomas.poelzler/

1 Department of Philosophy, University of Graz, Attemsgasse 25/II, 8010 Graz, Austria
} 
(i.e., observer-independent) moral truths (Brink 1989; Huemer 2005: p. 4; Joyce 2007a; Miller 2009, 2014). Realists believe that moral sentences are truth-apt, that some of these sentences are true, and that they are true in an objective sense (e.g., Brink 1989; Moore [1903] 1993; Railton 1986; Shafer-Landau 2003). Anti-realists deny at least one of these claims. Thus, according to them, sentences such as "Torturing puppies for fun is morally wrong" or "We ought to maximize happiness" are either not truth-apt (in a robust sense) at all (e.g., Ayer [1936] 1952; Blackburn 2000); are all untrue (e.g., Joyce 2001; Mackie [1977] 2011); or are, if true, only subjectively true (e.g., Firth 1952; Harman 1996; Prinz 2006, 2007). ${ }^{1}$

For most of its history the question of the existence of objective moral truths has mainly been addressed through rational argument and reflection. In the last decades, however, the debate's methodology has broadened. In line with a general trend in philosophy, an increasing number of metaethicists have also begun to appeal to scientific data in support of their views, such as data from experimental psychology, neuroscience and evolutionary biology. These "science-based" arguments for moral realism and anti-realism, as I will henceforth call them, can be defined as involving two parts. First, it is argued or assumed that the available scientific evidence supports a particular empirical hypothesis about morality. And second, it is argued that (some particular variant of) moral realism or anti-realism entails or suggests the truth or falsity of this empirical hypothesis, and is hence (likely) true or false. ${ }^{2}$

So far most prominent science-based arguments have been put forward in favor of moral anti-realism. ${ }^{3}$ Proponents of evolutionary debunking arguments, for example, start from the scientific hypothesis that moral judgements are a product of natural selection. They then argue that as natural selection would have equipped us with such judgements whether or not they are true, we are either not justified in making any moral judgement (e.g., Joyce 2007b) or objective moral truths do not exist (Street 2006). Another recent science-based argument (Prinz 2006, 2007) purports to show that moral judgements are constituted by dispositions to have emotions (which suggests that they do not represent objective moral facts). This claim about the nature of moral judgements is supposed to provide the best explanation of various psychological findings about the empirical relation between moral judgements and emotions. According to the so called argument from moral disagreement, finally, research in cultural psychology and anthropology suggests fundamental moral disagreement, which

\footnotetext{
1 Note that most of my below considerations hold on plausible alternative definitions of moral realism and anti-realism as well. For example, even if one believes that the moral realism/anti-realism debate concerns whether moral sentences are truth-apt and some of them are true (Sayre-McCord 1988: p. 5), or if one prefers a different conception of objectivity than the one assumed above (e.g., Horgan and Timmons 2008: p. 270), one should be able to find much of interest in this paper.

2 According to the above definition, an argument need not be positive in order to qualify as a science-based argument for moral realism or anti-realism. It can also be meant to refute any (particular variant of) these views. Hence, some of the arguments that I refer to as science-based arguments for moral realism and anti-realism are, strictly speaking, rather arguments against (a particular variant of) these views, or are arguments for these views only insofar as they purport to undermine some or all of their competitors.

3 A prominent science-based realist argument was put forward by Nicholas Sturgeon (1984, 1986). According to Sturgeon, we have reason for believing in the existence of objective moral truths because these truths are part of our best explanation of some scientific (and non-scientific) observations that we make.
} 
is best explained by, and hence supports that there are no objective moral truths (e.g., Doris and Plakias 2008; Fraser and Hauser 2010; Mackie [1977] 2011: pp. 36-37). ${ }^{4}$

With the rise of the scientific approach to moral realism and anti-realism, resistance against this approach has become more widespread and sophisticated as well. Most often science-based arguments have been criticized on the object-level, i.e., either by showing that their particular empirical hypothesis is unsupported by the available scientific evidence (e.g., Machery and Mallon 2010; May 2014; Meyers 2013; Pölzler 2015, 2016, forthcoming a, b), or by questioning this hypothesis' supposed metaethical implications (e.g., Enoch 2009; FitzPatrick 2014, 2015; Loeb 2007; Shafer-Landau 2012). In addition, however, one occasionally encounters a more sweeping metatheoretical scepticism about the scientific approach as well. Arguments such as those mentioned above cannot possibly work, it is claimed, because scientific evidence is generally irrelevant to determining the existence of objective moral truths.

Some metatheoretical objections against the scientific approach can be dismissed rather easily. For example, contrary to what has been argued by philosophers such as Russell (1918: p. 107) and Ayer ([1936] 1952: p. 51, 57), it is implausible that scientific evidence is irrelevant to assessing any philosophical claim at all (see Knobe and Nichols 2007: p. 3; Prinz 2007: p. 190, 2015: p. 3). Other objections, in contrast, have so far been given much less attention than they deserve. Most importantly, critics have argued that science-based arguments for moral realism and anti-realism fail because (1) they impermissibly derive normative from descriptive propositions, (2) they beg the question against non-naturalist moral realism, (3) science cannot inform conceptual accounts of moral judgements, and (4) the conceptual is logically prior to the empirical.

My main aim in this paper is to clarify and critically assess these prominent metatheoretical objections against the scientific approach to the existence of objective moral truths (Sects. 1-4). Moreover, based on this assessment, I will formulate four general requirements that science-based arguments in favor of moral realism and anti-realism should meet (Sect. 5). ${ }^{5}$ It will turn out that these arguments are limited in several ways, and that some existing arguments have been unsound. Yet it is still possible in principle for the empirical sciences to contribute to the moral realism/anti-realism debate.

\section{The objection from Hume's law}

The first general objection against science-based arguments to be considered traces back to David Hume. Hume famously maintained that no argument from exclusively descriptive premises to normative conclusions can be deductively valid ([1740] 1978: pp. 469-470). This principle, henceforth called "Hume's Law", has since been the by far most important source of skepticism about the relevance of empirical data for ethics. It has also occasionally been invoked by critics of science-based arguments for

4 The argument from moral disagreement traces as far back as to ancient Greece (Gowans 2000). Until the late twentieth century, however, its underlying empirical hypothesis has only rarely been claimed to be supported by science.

5 While my focus in this paper is exclusively on the moral realism/anti-realism debate, some of the lessons that will be drawn apply to scientific approaches to other philosophical debates as well. This is particularly true for Sects. 4 and 5. 
moral realism and anti-realism. Roughly, the objection goes as follows. In inferring moral realism or anti-realism from scientific hypotheses one derives an "ought" (a normative proposition) from an "is" (a descriptive proposition). Thus, given Hume's Law, no such argument can be valid.

Ronald Dworkin, for instance, rejects the idea that scientific data could support a non-cognitivist version of anti-realism as follows:

[S] ome moral philosophers have thought that some scientific discoveries about diversity in moral opinion and about the efficacy of moral convictions as motivation, for instance - prove that no moral claim can be true or false. But they are wrong: no theory about the best answer to any of these factual questions entails that moral judgments can or cannot be true. To think otherwise is to violate Hume's principle. (Dworkin, as cited in Shafer-Landau 2010: p. 483)

And according to Matthew Kramer,

[...] although modern science does not go any way toward impugning the reality of moral properties, it does not vindicate their reality, either. [...] anyone who seeks to uphold the reality of moral values will have to have recourse to moral considerations and moral argumentation. (Kramer 2009: pp. 204-205)

Dworkin and Kramer both assume that (variants of) moral realism and anti-realism are normative propositions. As Hume's Law forbids deducing such propositions from exclusively descriptive propositions, and scientific hypotheses are descriptive propositions, they deny that science can make any contribution to the moral realism/anti-realism debate.

\section{The objection from Hume's law}

(P1) Normative propositions cannot be validly deduced from exclusively descriptive propositions.

(P2) Scientific hypotheses are descriptive propositions.

(P3) Moral realism and anti-realism are normative propositions.

Ergo: Any argument from scientific hypotheses to moral realism or anti-realism is invalid.

There is a natural response to this objection against science-based arguments. Hume's Law forbids inferring normative conclusions from descriptive premises. But moral realism and anti-realism, it seems, are not normative propositions. They are rather descriptive propositions about such propositions, i.e., second-order or metaethical propositions. Thus, Richard Joyce, for example, writes: “[e]ven if there were an a priori prohibition on deriving evaluative conclusions from factual premises, this need not stand in the way of metaethical implications being drawn from factual premises, for a metaethical claim is not an ethical 'ought' claim; it is more likely to be a claim about how we use the word 'ought' in ethical discourse, which is a perfectly empirical matter" (2008: p. 372; see also Prinz 2015: p. 28).

Taken by itself, however, this response may not suffice for rescuing the scientific approach. For one thing Dworkin (1996) and Kramer (2009) have provided serious arguments for moral realism and anti-realism being normative rather than descriptive 
propositions. Even though these arguments appear weak, proponents of the above response would have to address them. For another thing many science-based arguments do not attempt to directly support moral realism and anti-realism in the first place. Their conclusions are rather epistemic claims which are then said to be best explained by, or in some other sense "fit" either moral realism or anti-realism (such as the claim that we are not justified in making any moral judgement; see Joyce 2001: pp. 166-169, 2007b: p. 181; Loeb 1998: pp. 285-286). ${ }^{6}$ Epistemic propositions, however, are just as normative as moral ones: they are propositions about what we ought to believe. Hence, granting Hume's Law, these propositions cannot be validly deduced from exclusively descriptive propositions either (Kumar: forthcoming).

Let us then, at least for the sake of the argument, assume that Dworkin and Kramer are right that science-based arguments for moral realism and anti-realism have normative conclusions. In what follows I will suggest that even then their objection fails. One reason for this failure is that in the strong sense in which Hume's Law is assumed by the objection this principle simply might not hold, and might also beg the question against particular variants of moral realism and anti-realism. ${ }^{7}$ Here, however, I will focus on a more obvious flaw. Dworkin's and Kramer's objection also fails because it is based on a number of misinterpretations of Hume's Law and/or of science-based arguments.

To begin with, Hume's Law is commonly understood as forbidding only deductive inferences from exclusively descriptive to normative propositions, i.e., inferences in which the truth of the premises necessitates the truth of the conclusion (Huemer 2005: pp. 72-74; Pigden 1989: pp. 130-131; Shafer-Landau 2010: pp. 485-486). ${ }^{8}$ Most science-based arguments for moral realism and anti-realism, however, have an inductive (probabilistic) form. In putting forward his argument from moral disagreement, John Mackie ([1977] 2011: pp. 36-37), for example, makes very clear that he does not attempt to establish that there are no objective moral facts. He rather proposes an

\footnotetext{
6 According to Joyce's above-mentioned evolutionary debunking argument, considerations about the evolution of moral judgements suggest that none of these judgements is epistemically justified. This skeptical conclusion is consistent with moral realism. However, even most realists themselves acknowledge that it puts significant pressure on their view. According to Russ Shafer-Landau (2012: p. 1), for example, the claim that we cannot have moral knowledge "leaves realists in the deeply unappealing position of being saddled with a thoroughgoing moral skepticism - a logically coherent position that contains about zero appeal." While Joyce does not link his skeptical conclusion to anti-realism himself, another proponent of science-based arguments, Don Loeb, does so. On Loeb's view, the existence of widespread moral disagreement suggests that even if there were objective moral truths, it may be impossible for us to epistemically access these truths. And this fact is best explained by, and hence supports that there simply are no such truths (Loeb 1998: pp. 285-286).

7 In order for Dworkin's and Kramer's objection to work arguments from descriptive premises to moral conclusions need not only be deductively invalid in a formal, but also in an analytic sense, i.e., no descriptive term must conceptually entail any normative term (for the distinction between these two versions of Hume's Law see Pigden 1989: p. 128, 2011; Salwén 2003: pp. 17-18). According to particular variants of moral realism and anti-realism, however, certain descriptive terms (such as being commanded by God, or maximizing happiness) do conceptually entail certain normative terms (such as being good).

8 Hume himself likely intended his principle to apply exclusively to deductive inferences as well ([1740] 1978: p. 457). In contrast to many contemporary proponents of the principle, however, he was of course generally skeptical of induction. On his view moral judgements accordingly are not derived from reason at all, but are rather based in sentiments.
} 
inference to the best explanation. As anti-realism "more readily explain[s]" ([1977] 2011: p. 37) the hypothesis that people widely and persistently disagree about moral questions than realism, anti-realism is claimed to be likely true.

To be fair, there may be grounds for believing that arguments from descriptive premises to normative conclusions cannot even be inductively valid. But Dworkin's and Kramer's objection even fails if one assumes Hume's Law in this stronger sense. As it was originally conceived, and as it has been held by almost all subsequent proponents, Hume's Law only forbids inferences from exclusively descriptive premises to normative conclusions (e.g., Huemer 2005: pp. 72-74; Pigden 1989: p. 28, 2011; see Kumar: forthcoming). It does not ban inferences from both descriptive and normative premises. Most science-based arguments for moral realism and anti-realism, however, involve normative premises in addition to their descriptive ones as well. Recall, for example, the above-mentioned evolutionary debunking argument by Joyce. This argument is not only grounded in the descriptive premises that humans' moral judgements have been influenced by natural selection, and that natural selection is insensitive to the truth of these beliefs. Joyce also endorses the normative proposition that we are epistemically unjustified to have beliefs that are caused by truth-insensitive processes of belief-formation (2007b: pp. 179-180, 211-219). ${ }^{9}$

Finally, suppose some science-based argument for moral realism and anti-realism does not involve any premise that is ordinarily considered normative. Even then Dworkin's and Kramer's objection fails to apply. For most arguments of this kind at least involve metaethical premises (such as the premise that the truth of claims about the meaning of moral concepts is determined by the intuitions of competent ordinary speakers, see Sect. 4 below); and proponents of the objection from Hume's Law typically hold that not only moral realism and anti-realism, but any metaethical proposition is normative (e.g., Dworkin 2011: pp. 10-11; Kramer 2009: pp. 4-5). By their own lights these science-based arguments thus do not infer normative from exclusively descriptive propositions either. They infer a normative conclusion (moral realism or anti-realism) from a set of descriptive (scientific) and normative (metaethical) premises.

\section{The objection from non-naturalism}

Perhaps unsurprisingly, many of the staunchest critics of science-based arguments for moral realism and anti-realism tend towards non-naturalist realism (the view that there are objective moral facts, and these facts are non-natural). ${ }^{10}$ Several non-naturalists

\footnotetext{
9 In fact, even the claim that natural selection is insensitive to the truth of moral beliefs may be normativein particular, moral-rather than descriptive. In order for this claim to be established one needs to make assumptions about what it is for a moral belief to be true (see, e.g., Schafer 2010: pp. 480-481; Vavova 2014: pp. 91-93).

10 Unsurprisingly, because science-based arguments have so far mainly been put forward in favor of antirealism; and because in contrast to non-naturalism, naturalism typically has strong affinities to science (see, e.g., Brink 1989; Boyd 1988). Another metaethical position which stresses the differences between ethics and science is divine command theory: the view that an action is morally right if and only if it is commanded by God (e.g., Quinn 2000). In fact, divine command theorists may easily come up with an analogous version of the objection discussed in this Section.
} 
have in particular suggested that appeals to science beg the question against their view. According to them, scientific observation and experimentation cannot possibly contribute to detecting non-natural facts. These methods have been designed to investigate only natural aspects of the world. When we turn to science in exploring whether there are non-natural moral facts we will therefore necessarily arrive at the conclusion that these facts do not exist.

David Kaspar, for example, points out how science presupposes the falsity of nonnaturalist moral realism as follows:

The scientific picture of the natural world convinces moral nihilists that there is no room for moral properties at all. (Kaspar 2012: p. 76)

But does science itself endorse moral nihilism? No, it does not. [...] it is rather the presuppositions of the natural sciences that are employed against moral realism. (Kaspar 2012: p. 79)

From science's inability to detect non-natural moral facts Kaspar then infers that it cannot contribute to ethics:

[...] we should not hold that just because science has indisputable epistemic reign over all physical domains of inquiry that it has dominion over all domains of inquiry. [...] moral knowledge is beyond the reach of the sciences. (Kaspar 2012: p. 77)

Russ Shafer-Landau raises a similar worry. As philosophical truths are essentially non-natural, and ethical truths are a species of philosophical truths, ethical truths must be non-natural too-and hence inaccessible to science:

Dismissing such things [philosophical truths] from our ontology, or ratifying their inclusion in it, is something that no scientist is able to do. Such things are dealt with in an a priori way. [...] As ethics is a branch of philosophy, we have excellent reason to think that fundamental ethical principles share the same status as fundamental philosophical principles. (Shafer-Landau 2006: pp. 216-217)

In short, then, the worry raised by non-naturalists is that science presupposes the falsity of non-naturalist moral realism, and therefore cannot be validly appealed to in assessing moral realism's truth.

\section{The objection from non-naturalism}

(P1) Non-naturalism centrally claims that moral truths are non-natural.

(P2) Scientific methods cannot possibly yield evidence for the existence of nonnatural entities.

Ergo: Science-based arguments about the existence of (objective) moral truths beg the question against non-naturalism.

In Sect. 4 below I will argue that in investigating the existence of objective moral truths one must strive for a wide reflective equilibrium which involves scientific propositions about morality and propositions about non-moral issues just as well as metaethical ones. In light of this methodology charges of "begging the question" may turn out 
unwarranted even if premises of science-based arguments presuppose the falsity of particular variants of moral realism or anti-realism. These premises' coherentist justification may be so much stronger than the justification of the respective variants of moral realism or anti-realism that they still provide valid considerations against these variants. In what follows, however, I will suggest that the objection from non-naturalism even fails on traditional foundationalist grounds. Both the semantic presuppositions of moral realism and anti-realism and these views' metaphysical claims can be scientifically investigated in ways that do not beg the question against non-naturalism.

\subsection{Non-naturalism and scientifically informed moral semantics}

Moral realism and anti-realism are metaphysical claims (Devitt 1991a, b, 2002; Miller 2014). Yet their truth also depends on the semantic issue of what, if anything, we purport to refer to when we judge a thing morally right, wrong, good, bad, etc. (see Huemer 2005: pp. 4-7; Kauppinen 2008a: p. 27; Loeb 2008; Shafer-Landau 2003: p. 17). ${ }^{11}$ Non-naturalist realism presupposes that moral judgements purport to represent objective moral facts that are non-natural; naturalist realism presupposes that moral judgements purport to represent objective moral facts that are natural; and so on.

Many science-based arguments have attempted to support (particular variants of) moral realism or anti-realism by vindicating or falsifying these views' semantic presuppositions. In arguing against the widely shared assumption that all moral judgements have the same meaning and reference Michael Gill (2009), for example, appeals to psychological research on folk metaethics according to which ordinary people's intuitions about the truth-aptness and truth of moral sentences vary. Another prominent argument of this kind is Prinz's above-mentioned argument for sentimentalism (2006, 2007). On Prinz's view studies about the neural correlates of moral judgements, the influence of disgust on these judgements, etc. suggest that what it means to make a moral judgement is to have a disposition to have emotions.

Science-based arguments in moral semantics may be deemed problematic for various reasons (see Sects. 3 and 4). But why are we to believe that such arguments must be biased against non-naturalism? It would clearly be implausible to claim such a bias on grounds of the methods of semantically relevant psychological studies being inapt to detect non-natural moral facts. After all, studies on folk metaethics, the relation between moral judgements and emotions, etc. do not purport to investigate moral facts in the first place (in the normative sense in which these facts are addressed by moral realists and anti-realists). They are rather concerned with scientific facts about morality. If science-based arguments in moral semantics are to involve a bias against nonnaturalism it must thus rather be explained by these arguments' philosophical assumptions. But without further argument this version of the objection is implausible too.

There is no point in denying that some science-based arguments in moral semantics do involve anti-non-naturalist assumptions. Some arguments, for example, are based

\footnotetext{
11 In this paper I use the label "moral semantics" in a broad sense, to include conceptual questions that are sometimes discussed under the heading of (philosophical) moral psychology (in particular, the question of what it is to make a moral judgement).
} 
on externalist approaches to moral semantics (according to which the meaning or reference of moral sentences is determined by factors external to our minds), and such approaches fit naturally with the semantic presuppositions of naturalist moral realism (e.g., Brink 1989; Boyd 1988). Many other arguments, however, seem to be perfectly theoretically neutral with regard to the natural/non-natural distinction. This also holds for the two kinds of arguments that I will defend in Sects. 3 and 4: arguments that purport to justify semantic claims by appealing to ordinary speakers' conceptual intuitions (as proposed by Gill), and arguments that do so on grounds of these claims best explaining psychological or other scientific facts about morality (such as Prinz's argument).

As to conceptual intuitions arguments, they are based on an internalist approach to moral semantics which does not disadvantage non-naturalism at all. In fact, when philosophers have appealed to ordinary people's conceptual intuitions they have sometimes done so precisely to vindicate non-naturalism's semantic presuppositions. According to Mackie, for example, considerations about what "[t]he ordinary user of moral language means" suggest that moral terms involve a "claim to objective, intrinsic, prescriptivity" ([1977] 2011: pp. 33-35). ${ }^{12}$

Best explanation arguments along the line of Prinz's do not beg the question against non-naturalism either. There is no reason for believing that the available scientific evidence about moral judgements cannot best be explained by the claim that these judgements are constituted by beliefs (or more specifically, beliefs about the exemplification of non-natural properties). Elsewhere I show that this result is even likely (see Pölzler forthcoming c).

\subsection{Non-naturalism and scientifically informed moral metaphysics}

Not only can the empirical sciences inform the moral realism/anti-realism debate's semantic presuppositions without begging the question against non-naturalism, but its main metaphysical claims as well. This is trivially true on the basis of a naturalist semantics, i.e., assuming that moral sentences purport to represent natural facts (such as, for example, facts about what maximizes happiness). For natural facts are obviously principally accessible by scientific methods. But suppose Kaspar (2012: p. 76), Shafer-Landau (2006: p. 210) and other non-naturalists were right that moral judgements purport to represent specifically non-natural facts. Even then, I believe, scientific evidence could be relevant to determining whether (objective) moral facts exist.

First, the empirical sciences may yield direct evidence for the existence of nonnatural moral facts - or at least they may do so on most plausible understandings of

\footnotetext{
12 Two things are important to note here. First, in contrast to proponents of the scientific approach, Mackie did not appeal to psychological or linguistic findings in justifying his claim about ordinary speakers' conceptual intuitions. He rather generalized from his own reflective participation in moral discourse. And second, while Mackie accepted the semantic presuppositions of non-naturalism he of course was not a non-naturalist all things considered. On his view the non-natural moral properties that we refer to when we judge actions morally right, wrong, good, bad, etc. do not exist, and hence all of these judgements are false.
} 
the natural/non-natural distinction. ${ }^{13}$ Like many others Shafer-Landau, for example, assumes that a moral property is non-natural if and only if it is "discoverable a priori" (2006: p. 212; see also Blackburn 2006: p. 160; Copp 2003: pp. 181-187, 2004: pp. 12-13). ${ }^{14}$ But that a kind of properties can be known a priori does not by itself entail that it is not amenable to scientific inquiry. This is because on some plausible accounts of a priori knowledge, propositions can be known both a priori and empirically. A famous illustration of this claim is the question of whether a particular number is a prime (Kripke 1980: p. 35). The answer to this question cannot only be known by doing the necessary calculations, thus "seeing" its truth, but also by consulting a computer. In this latter case one exclusively relies on empirical evidence, such as evidence about how the computer was built, how the laws of physics work, etc.

Second, regardless of one's understanding of the natural/non-natural distinction, scientific evidence may be at least indirectly relevant to determining the existence of non-natural moral facts. As explained above, many scientifically-minded metaethicists purport to support realism or anti-realism by establishing epistemic conclusions, in particular the conclusion that we are not justified in making any moral judgement (which is widely thought to support anti-realism, see fn. 6). Arguments of this kind often do not involve any assumptions regarding the existence of (non-natural) moral facts at all. In putting forward his above evolutionary debunking argument Joyce (2007b), for example, only claimed that if there were (objective) moral facts (which, in the context of this argument, he neither affirms nor denies) ${ }^{15}$ then, given the influence of natural selection, we would not be justified in making judgements about these facts. Given that epistemic science-based arguments for moral realism or anti-realism neither attempt to directly establish claims about the existence of (objective) moral facts nor assume such claims as premises, it is unclear why they should necessarily beg the question against the existence of objective non-natural moral facts. At least proponents of the non-naturalist objection owe us arguments for this conclusionwhich so far they haven't provided.

\section{The semantic objection}

In Sect. 2 I suggested that moral realism and anti-realism involve semantic presuppositions. Inquiries into these presuppositions are crucial to determine the existence of objective moral truths. In fact, depending on their outcome, they may even be sufficient. Suppose, for example, moral sentences purported to represent incoherent moral facts (analogously to sentences about "round squares"; e.g., Loeb 2008), or that

\footnotetext{
13 On certain understandings of this distinction non-natural moral facts cannot be directly scientifically detected. Most importantly, this holds true for so called disciplinary definitions: definitions according to which a moral fact qualifies as non-natural if and only if it is not the subject matter of actual or ideal versions of the (natural) sciences (e.g., Brink 1989: p. 22; Moore [1903] 1993: p. 92). For convincing arguments against such definitions see Ridge 2014; Tropman 2008: pp. 168-169.

14 Kaspar characterizes the natural/non-natural distinction in a confusing variety of ways (2012: p. 75, 80, 100).

15 Of course, Joyce denies the existence of objective moral facts for independent reasons (see in particular 2001).
} 
they did not purport to represent any kind of (robust) moral facts at all (analogously to "boo" or "hooray" sentences; e.g., Ayer [1936] 1952; Blackburn 2000; Gibbard 1990). Of course, this would not affect which kinds of facts exist in the world. But it would imply that whatever facts do exist, none of them deserve to be called moral. One would hence have shown that there are no moral facts (see Huemer 2005: pp. 4-7; Kauppinen 2008a: p. 27; Loeb 2008: p. 355; Shafer-Landau 2003: p. 17).

Given moral semantics' evidential weight, for the empirical sciences to make substantial contributions to the moral realism/anti-realism debate (or maybe even any contribution at all) they need to support claims in these areas. Proponents of the third metatheoretical objection against science-based arguments that I would like to discuss deny that this is logically or methodologically possible. According to them, plausibly achievable scientific data is irrelevant to analyzing the meaning or reference of moral sentences (e.g., Kauppinen 2008b; Sayre-McCord 2008), or even of any kind of sentences (e.g., Cullen 2010; Kauppinen 2007; Ludwig forthcoming; Sosa 2007). Antti-Kauppinen, for example, writes:

[...] questions about what counts as moral judgment can[not] be answered empirically, by running surveys of ordinary people's responses to particular cases. (Kauppinen 2008b: p. 23, fn. 42)

Elsewhere Kauppinen even doubts the relevance of scientific evidence for the analysis of any concept: ${ }^{16}$

[...] conceptual claims [...] cannot be tested with methods of positivist social science. (Kauppinen 2007: p. 95)

[...] as philosophers, we continue to participate in ordinary linguistic practices, but do so reflectively, paying careful attention to what is appropriate and why and drawing on the insights of those who have explored the same paths before. Running a poll provides no shortcut in this business of reaching a better conceptual self-understanding. (Kauppinen 2007: p. 113)

In short, then, proponents of the semantic objection argue that (most) science-based arguments must be rejected because moral realism and anti-realism are centrally committed to claims about the meaning or reference of moral sentences, and plausibly achievable scientific data cannot have any implications for such claims.

\section{The semantic objection}

(P1) The truth of moral realism and anti-realism crucially depends on the meaning and reference of moral sentences.

(P2) Plausibly achievable scientific evidence is (largely) irrelevant to assessing the meaning and reference of (moral) sentences.

Ergo: Plausibly achievable scientific evidence is (largely) irrelevant to assessing the truth of moral realism and anti-realism.

16 While Kauppinen denies that science can contribute to the analysis of (moral) concepts, he acknowledges that it is relevant to metaethics and philosophy in other ways (2008a: p. 18). 
The plausibility of the above objection against science-based arguments in moral semantics depends to some extent on one's general approach to (moral) semantics. On externalist views science can uncontroversially advance moral semantics. By analogy, just consider how scientific discoveries contributed and were in fact inevitable to reveal that our ordinary concept of water (a classic example of externalist analyses) refers to $\mathrm{H}_{2} \mathrm{O}$. While semantic externalism is plausible with regard to some subject matters, however, it is not plausible with regard to morality. Moral properties, if there are such things, cannot be as easily identified and pointed to as water, and without knowledge of their underlying nature. They also lack any other feature that favors externalist analyses (Finlay 2008; see also Laskowski and Finlay forthcoming; Pigden 2012). ${ }^{17}$ So are there ways in which science can inform moral semantics on an internalist approach as well?

In what follows I will advocate a positive answer to this question, endorsing in particular two kinds of science-based arguments: (1) arguments based on scientific studies about conceptual intuitions, and (2) arguments according to which certain claims in moral semantics are likely true because they provide the best explanation of scientific findings.

\subsection{Conceptual intuitions arguments}

Given semantic internalism, claims about the meaning and reference of concepts are to be tested against the conceptual intuitions of competent ordinary speakers, i.e., against these speakers' pre-theoretical dispositions to apply concepts in some cases but not in others. The more a claim matches these intuitions, the higher its warrant (e.g., Jackson 1998: p. 31; Kauppinen 2007: pp. 96-98; Loeb 2008: p. 356). For the semantic objection against science-based arguments to succeed on the assumption of semantic internalism it would therefore have to be impossible for science to contribute to the study of ordinary speakers' intuitions about moral concepts. Some philosophers have indeed denied such contributions.

Kauppinen (2007: pp. 100-107) put forward three highly influential arguments to this conclusion. According to him, only our "robust"-as opposed to "surface"intuitions bear on moral semantics. But science is unable to reveal these intuitions. First, whether a speaker is competent with regard to a concept is a normative rather than a descriptive question, and can hence not be tested by science. Second, conceptual intuitions in scientific studies may not occur under sufficiently ideal conditions (conditions "in which there are no perturbing, warping or distorting factors or limits of information, access or ability”, 2007: 103). And third, these studies also cannot ensure that subjects' responses are exclusively influenced by semantic rather than pragmatic considerations, i.e., by considerations about meaning rather than context, speaker intention, etc.

\footnotetext{
17 In addition to externalism, one may also attempt to bring psychological theories of concepts to bear on the moral realism/anti-realism issue (e.g., Goldman 1993: p. 340). Arguments of this kind do not seem promising, though. For as has in particular been argued by Machery (2009: pp. 31-51), in investigating concepts psychologists and philosophers seem to aim at answering different kinds of questions.
} 
Kauppinen's objections point to important limitations and problems of scientific studies on conceptual intuitions. However, even if we grant his (plausible) assumption that only robust intuitions are semantically relevant he still fails to prove such studies generally philosophically insignificant. In response to the first objection note that scientists do not need to establish accounts of conceptual competency in the first place. First, any subject who is conceptually incompetent in obvious ways (such as subjects who are found to apply the concept "morally right" to the behavior of insects) may be excluded from analysis independently of such accounts. And second, at least in a conditional sense scientists may also adopt more controversial competency constraints, as they have been developed by traditional philosophical methods. Suppose, for example, a study on moral concepts assumes that it is a sign of incompetency to allow for prudential, aesthetic or other non-moral judgements to override moral judgements (Hare 1963: pp. 168-169). Even though the results of this study may be irrelevant to metaethicists who reject this assumption, they may still contribute to refining and extending theories which do regard moral judgements as overriding (Nadelhoffer and Nahmias 2007: p. 134; Sytsma and Livengood 2016: pp. 108-109).

Moreover, Kauppinen's non-ideality and pragmatic influences objections fail in that they underestimate the methodological sophistication obtainable by scientific studies on ordinary speakers' conceptual intuitions. These studies can (and sometimes do) involve large samples; instruct subjects to consider scenarios, questions and responses carefully; give them sufficient time for their responses; include manipulation checks which indicate whether subjects really understood what they were presented with; etc. Given the nature of statistical analysis, provisions such as these make it highly likely that (otherwise valid) studies of the above kind measure subjects' robust conceptual intuitions, rather than non-ideal or pragmatic influences (Horvath 2010: pp. 453-454; Nadelhoffer and Nahmias 2007: pp. 135-136; Sytsma and Livengood 2016: pp. 100_ 107).

\subsection{Best explanation arguments}

A second promising form of science-based arguments in moral semantics appeals to scientific evidence other than about conceptual intuitions. According to such arguments, this evidence supports claims about what it means to make a moral judgement in virtue of being best explained by these claims.

As a prominent example recall the above argument by Jesse Prinz (2006, 2007: 26-29). Prinz claims that research in empirical moral psychology shows moral judgements to be closely empirically associated with emotions in four ways: (1) strong emotions reliably co-occur with moral judgements, (2) emotions often and substantially causally influence moral judgements, (3) emotions are often causally sufficient for moral judgements, and (4) emotions are causally necessary for moral judgements. These findings may be explained by all sorts of conceptual accounts. However, Prinz argues in detail, their best explanation is that to make a moral judgement means to have a disposition to have certain emotions. This claim is therefore likely true.

Best explanation arguments in moral semantics are not subject to the above objections by Kauppinen. However, they may be criticized in a different metatheoretical 
way, namely based on the apparent logical priority of the conceptual over the empirical. In order for scientists to be able to properly test hypotheses about moral judgements they must make at least some assumptions about what the term "moral judgement" means. Otherwise they may end up investigating non-moral judgements. But if these scientific studies presuppose a theory of the nature of moral judgements, how can they then possibly provide valid evidence regarding such theories?

Some philosophers have suggested that on closer consideration all science-based arguments for moral realism and anti-realism-or even all science-based arguments in metaethics or philosophy more generally — are subject to the objection from logical priority. In the next Section I will accordingly consider this objection in detail.

\section{The logical priority objection}

Any scientific hypothesis that can plausibly be said to bear on the moral realism/antirealism debate in some sense or another concerns our moral judgements: their evolution, their relation to emotions, the widespreadness of disagreement about them, and so on. The scientific hypotheses underlying science-based arguments for moral realism and anti-realism therefore seem to be contingent on what such judgements are. At first sight this contingency may be deemed unproblematic. If a psychiatrist attempts to investigate the effectiveness of a new drug against depression, or an astronomer attempts to investigate the properties of black holes, they cannot but make assumptions about what it is to suffer from depression or to be a black hole either. So isn't the apparent contingency of the empirical on the conceptual just a general feature of scientific research?

While this is indeed true, in the context of science-based arguments for moral realism and anti-realism the above-mentioned contingency nevertheless seems to be especially problematic. In particular, it has been claimed to give rise to two related problems: the controversiality and the theoretical neutrality problem.

\subsection{The controversiality problem}

Compared to depression, black holes, and many other subject matters of scientific study the meaning of the term "moral judgement" is much more controversial. ${ }^{18}$ For example, philosophers disagree about whether such judgements must be about harms or benefits (see, e.g., Foot 1978 vs. Haidt and Joseph 2007); whether they entail categorical reasons for action (see, e.g., Kant 1993 vs. Foot 1972); whether and in which sense they entail motives to act according to them (see, e.g., Smith 1994 vs. Svavarsdóttir 1999); and so on. By presupposing a theory of the nature of moral judgements scientific studies hence threaten to become conceptually controversial themselves. Any critic of these studies (and of empirical and metaethical positions

\footnotetext{
18 Of course, there is disagreement about what concepts such as depression or black hole mean as well. In contrast to the case of moral judgements this disagreement is far less widespread, however, and typically concerns the fringes rather than the core of the respective concepts.
} 
which they are supposed to support) may question their results on grounds of their failing to address moral judgements.

Richard Joyce has recently noted this "controversiality problem" with regard to the hypothesis that moral judgements are adaptations:

[...] the notion of moral judgment is sufficiently pliable as to allow of different legitimate precisifications. [...] It is possible (and not unlikely) that on any precisification of "moral judgment" [...] moral nativism is false. But it is also possible that moral nativism is true for certain precifisications and false for others. Certainly the plausibility of various pro-nativist and anti-nativist arguments varies according to different conceptions of the target trait [... ${ }^{19}{ }^{19}$ (Joyce 2013:

p. 566)

\subsection{The theoretical neutrality problem}

The meaning of the term "moral judgement" does not only depend on these judgements' relation to reasons, motivation, etc., but also on whether such judgements purport to represent (objective) moral facts. In testing empirical hypotheses about these judgements scientists may therefore have to (implicitly) accept the semantic presupposition/s of one or several variant/s of moral realism or anti-realism. This implies that the results of their studies fail to be theoretically neutral with regard to the existence of objective moral truths. These results may hence be unable to ground (strong) arguments in favor of (certain) variants of moral realism and anti-realism.

In addition to several other scholars (see Bruni 2011; Joyce 2008: p. 387; and Bennett and Hacker 2003: p. 2 in a non-moral context), this "theoretical neutrality" problem has recently again been pointed out by Antti Kauppinen: ${ }^{20}$

[...] conceptual questions are inescapable and precede the empirical ones: to find out what leads to moral judgment or what brain states are correlated with it, we must first know what counts as a moral judgment. [...] this is [...] to say that $[\ldots]$ this work [scientific work] does not advance our understanding of the nature of moral thinking. [...] when we are trying to understand what it is to think that something is morally wrong, there are no harder data than convincing stories and plausible descriptions [...]. (Kauppinen 2008b: pp. 23-24)

The worry at issue, then, is that scientific investigations of moral judgements require an ex ante theory of the nature of these judgements, and that such investigations are accordingly conceptually controversial (Joyce) and/or biased against (particular variants of) moral realism or anti-realism (Kauppinen).

\footnotetext{
19 Note that Joyce does not only believe that the meaning of the term "moral judgement" is controversial, but even that there might be no determinate fact of the matter about this meaning. Two or more competing analyses of the term may be equally true.

20 Kauppinen raises this worry in the context of science-based arguments in the motivational internalism/externalism debate.
} 


\section{The Logical Priority Objection}

(P1) In testing empirical hypotheses about moral judgements scientists must make assumptions about what it is to make a moral judgement.

(P2) Theories about what it is to make a moral judgement are highly controversial and/or entail or suggest (variants of) moral realism or anti-realism.

Ergo: Scientific evidence about moral judgements is highly controversial and/or fails to be theoretically neutral with regard to moral realism and anti-realism. It thus cannot ground (strong) arguments about these views.

The controversiality and theoretical neutrality problems have important implications for the scientific approach to the existence of objective moral truths. However, like the other meta-theoretical objections considered in this paper, they fail to ground this approach's rejection as a whole.

To begin with, there is one kind of scientific evidence which neither needs to be conceptually controversial nor theoretically biased in the way explained above at all, namely evidence about ordinary people's intuitions about moral concepts, and about the truth of moral realism or anti-realism. ${ }^{21}$ As an example, consider two recent studies by Jennifer Wright et al. (2013, 2014). In these studies Wright et al. attempted to measure intuitions about moral realism and anti-realism by asking subjects for each of a number of sentences whether they regarded it as a moral sentence, and whether they believed the sentence to be "true", "false" or "just an opinion or attitude". This measure of folk moral realism lacks in construct validity (see Pölzler forthcoming b). However, and more importantly in our present context, Wright et al.'s studies do not suffer from any of the problems pointed out above (nor would they suffer from them if their measures were to be improved). As to the theoretical neutrality problem, the studies did not involve any ex ante commitment to semantic presuppositions of moral realism or anti-realism. In fact, intuitions about these presuppositions (Are moral sentences truth-apt?) are part of what Wright et al. attempted to measure in the first place. And regarding the controversiality problem, the item sentences that subjects were presented were not classified as moral/non-moral by the researchers, but rather by the subjects themselves. The study therefore did not involve ex ante commitments to any other claims in moral semantics (such as about whether moral judgements are necessarily about harms or benefits) either.

Most science-based arguments for moral realism and anti-realism are based on hypotheses that do not address folk moral semantics or folk moral realism. With regard to these arguments (such as evolutionary debunking arguments, Prinz's sentimentalist argument, and arguments from moral disagreement) the logical priority objection can have some force. However, it would be exaggerated to conclude that scientific evidence about moral judgements therefore cannot bear on the moral realism/anti-realism debate at all.

First, some scientific findings about moral judgements may hold up on (almost) any plausible account of what such judgements are-whether one takes them to entail

21 In his discussion of the theoretical neutrality objection Kauppinen briefly acknowledges this himself (2008b: p. 23, fn. 42). 
categorical reasons or not, whether one takes them to purport to represent (objective) moral facts or not, and so on. Second, in cases in which findings are sensitive to such accounts scientific research on moral judgements may again be understood in a conditional sense. It is still possible to show that if one defines moral judgements in a certain way then a particular hypothesis is scientifically well-supported, and may provide evidence in favor of moral realism or anti-realism (see Nadelhoffer and Nahmias 2007: p. 134). And third, and most importantly, given that both questions about what it means to make a moral judgement and about the truth of moral realism in general are so contested, it seems reasonable to give up on the idea of a strict logical priority of the conceptual over the empirical in the first place.

It is true that one's theory of the nature of moral judgements may sometimes reasonably lead one to reject the results of certain scientific studies (see Pölzler forthcoming c). Conversely, however, one should allow scientific evidence to bear on the nature of these judgements too. Contrary to one of Prinz's above-mentioned hypotheses, for example, a significant proportion of judgements that would pre-theoretically widely be considered moral have been found not to correlate with strong emotions (e.g., Greene et al. 2001, 2008; Pölzler 2015). In the face of the controversiality of the nature of moral judgements this finding provides at least some (defeasible) grounds for doubting that such judgements are constituted by occurrent emotions (as, e.g., claimed by Ayer [1936] 1952: p. 107). Moreover, given the plausible assumption that some subjects' judgements were made under what Prinz considers to be the manifestation conditions of emotional dispositions, the finding even casts doubt on his claim that moral judgements are constituted by dispositions to have emotions (see Pölzler forthcoming c)..$^{22}$

Given this more complex relationship between the conceptual and the empirical, I suggest substituting the logical priority assumption with a reflective equilibrium model. Claims about the nature of moral judgements and scientific hypotheses about these judgements must be reflected on as a whole. In particular, they must be continuously mutually adjusted, so as to finally reach a state where they are consistent and support or best explain each other (see Brax 2009: p. 4, 11; Levy 2011: p. W1; Toulmin 1971: 33-37). But even if this goal is reached one must not yet come to an end with one's investigations. This is because to the extent that the nature of moral judgements or the truth of relevant scientific hypotheses depend on claims about non-moral matters, these claims must be considered as well.

Consider, for example, the question of whether emotions have cognitive content, and hence function to represent facts (see, e.g., Nussbaum 2004 vs. James 1884). If this question is answered affirmatively the claim that moral judgements are constituted by (dispositions to have) emotions turns out much more plausible than if it is answered in the negative. For only if emotions do have cognitive content moral judgements can uncontroversially be said to be robustly truth-apt; embeddable in conditionals,

\footnotetext{
22 Prinz fails to provide any explicit account of the circumstances that activate moral sentiments. On one reasonable interpretation he holds that such an activation requires a moral judgement to be (1) about particular actions, (2) about simple actions, and (3) made by non-depressed persons (Prinz 2010: p. 4). Most of the moral judgements that were made in studies such as Greene et al.'s $(2001,2008)$ appear to fulfill these conditions. Yet, these judgements often did not correlate with (strong) emotions.
} 
propositional attitude statements, questions, etc.; and able to function as premises and conclusions in arguments (see Geach 1965). Moreover, as proponents of cognitivist and non-cognitivist theories of emotions regard different brain areas as indicative of emotional activity, they may even differ in their interpretation of scientific findings about moral judgements' mental correlates.

Ultimately, then, advancing our understanding of the existence of objective moral truths requires what has been called a "wide" reflective equilibrium (see Daniels 1979), i.e., we must consider a much more extensive array of evidence than has commonly been assumed.

\section{Implications for actual research}

In Sects. 1-4 I argued that the objection from Hume's Law, the objection from nonnaturalism, the semantic objection and the logical priority objection all fail to rule out scientific contributions to the moral realism/anti-realism debate. But that such contributions are (logically, methodologically, etc.) possible of course does not entail that they are likely, and even less that any contributions have already actually been achieved.

In fact, most existing science-based arguments for moral realism and anti-realism are rather unconvincing. Sometimes these arguments are based on misinterpretations of the current state of scientific research (e.g., Prinz 2006, 2007); other times they assume implausible philosophical claims (e.g., Casebeer 2003; Richards 1986). There are arguments which do not (sufficiently) rule out metaethically relevant alternative explanations of scientific findings (e.g., Doris and Plakias 2008); arguments which appeal to studies that employ inherently contested scientific methods (e.g., Prinz 2006, 2007; Joyce 2007b); arguments which are based on empirical hypotheses that have so far been insufficiently investigated (e.g., Doris and Plakias 2008; Fraser and Hauser 2010); and so on.

The provisions, modifications and further studies that would be necessary to alleviate the above problems are as manifold as these problems themselves. Some flaws, however, could in particular have been prevented if proponents of science-based arguments for moral realism and anti-realism had paid more attention to the metatheoretical objections considered above. Let me briefly explain these flaws and suggest how they might be avoided.

First, at least in a formal sense (considering the logical form of arguments) Hume was right that one must not deduce normative from purely descriptive propositions (Pigden 1989). In Sect. 2 I argued that no prominent existing science-based argument for moral realism and anti-realism violates this principle. To repeat, arguments of this kind are typically inductive rather than deductive, and they typically involve normative premises in addition to their descriptive (scientific) ones as well. Yet realist and antirealist appeals to scientific evidence can fail in virtue of violating Hume's Law So it does not hurt emphasizing that in developing such appeals this Law must be kept in mind.

Second, science-based arguments have been accused of begging the question against non-naturalist realism. In some cases this objection may be warranted. As mentioned above, for example, externalist approaches to (moral) semantics have an inbuilt ten- 
dency towards naturalism. Another case in point are anti-realist appeals to Harman's "best explanation criterion" (according to which we are only justified to believe in the existence of (moral) facts if these facts figure in the best explanation of observations that we make) (see Ruse 1998: pp. 253-254; Ruse and Wilson 1986: pp. 186-187). In order for this criterion to hold experience would have to be our only source of evidence-which, on certain understandings of non-naturalism (including the understanding discussed in Sect. 2), entails the falsity of non-naturalism. In light of the coherentist epistemology advocated in this paper such presuppositions may sometimes turn out innocuous. But at other occassions they might not, and in any case one should be aware of what ultimately grounds one's argument. My second piece of advice for proponents of science-based arguments hence is to consider more thoroughly how assumptions of these arguments relate to particular variants of moral realism and anti-realism.

Third, in our discussion of moral semantics we found Kauppinen arguing that ordinary people's conceptual intuitions can only matter for the analysis of moral judgements if these intuitions are robust, i.e., if they are had by competent users and do not reflect performance errors or pragmatic influences. This assumption is plausible. Yet sometimes metaethicists attempt to inform moral semantics by appeal to scientific studies that only measured subjects' surface intuitions. In arguing for his "variantist" view Gill, for example, inter alia appealed to a psychological study on folk metaethics by Goodwin and Darley (2008: p. 220, fn. 5, p. 222, fn. 7). This study did not test subjects' conceptual competency, and its measures to rule out non-ideal and pragmatic influences (such as having subjects explain their responses) were insufficiently executed. ${ }^{23}$ A third important requirement hence is that in grounding conceptual intuitions arguments philosophers must only appeal to scientific studies that address subjects' robust conceptual intuitions.

Fourth and finally, we found that scientific hypotheses about moral judgements are to some extent contingent on the meaning of the term "moral judgement". This contingency has not always been properly acknowledged. Recall, for example, how Prinz argued that his sentimentalist account of moral semantics is likely true because it best explains (among others) that emotions are sometimes causally sufficient for moral judgements (2006: p. 31, 2007: pp. 29-32). In motivating this empirical hypothesis Prinz only appealed to scientific studies. But the hypothesis is in need of conceptual justification too. After all, according to some philosophers, for a judgement to qualify as moral it cannot be exclusively caused by emotions. Moral judgements are necessarily based on (relevant) reasons (e.g., Rachels 1993: p. 483); or at least they would have to be retracted when the person who makes them finds out that they are not based on such reasons (e.g., Jones 2006: pp. 48-50; Sauer 2012: p. 106). I accordingly recommend to acknowledge any contingency of one's scientific hypotheses on the meaning of the term "moral judgement"-either by formulating these hypotheses in a

23 This observation must not be understood as a criticism of Goodwin and Darley. After all, they did not aim at providing semantically relevant evidence in the first place. Their interest was rather with illuminating the prevalence and causes of ordinary people's intuitions about the moral objectivism/subjectivism distinction (2008: p. 1341). 
conditional way or by doing what is ultimately to be done, namely working them into a reflective equilibrium with all relevant conceptual and empirical claims.

\section{Conclusion}

Can the empirical sciences contribute to the moral realism/anti-realism debate? In this paper I considered four prominent general objections against such contributions: (1) science-based arguments for moral realism and anti-realism impermissibly derive normative from descriptive propositions, (2) such arguments beg the question against non-naturalist moral realism, (3) science cannot inform conceptual accounts of moral judgements, and (4) the conceptual is logically prior to the empirical. It turned out that none of these objections succeed in ruling out the empirical sciences' relevance for the moral realism/anti-realism debate. However, they suggest four important general requirements for arguments of this kind. Such arguments should not deduce normative from exclusive descriptive propositions, should not beg the question against non-naturalism, should only appeal to studies that address robust rather than surface intuitions, and should consider any contingency of their scientific hypotheses on the meaning of the term "moral judgement".

As the above requirements have not always been met, and as realist and anti-realist appeals to scientific evidence tend to suffer from various other flaws as well, the significance of such evidence has so far been rather modest. However, most problems of science-based arguments can (and likely will) be solved. I therefore believe that in the end the most reasonable approach to the moral realism/anti-realism debate is ecumenical. In order to further increase our understanding of the existence of objective moral truths both traditional philosophical and scientific evidence about this issue must be taken into account, and must be integrated into a reflective equilibrium involving evidence about related non-moral issues as well.

Acknowledgements Open access funding provided by University of Graz. For helpful comments I would like to thank David Enoch, the paper's reviewers, and audiences at the Hebrew University of Jerusalem and the Ben-Gurion University of the Negev.

Open Access This article is distributed under the terms of the Creative Commons Attribution 4.0 International License (http://creativecommons.org/licenses/by/4.0/), which permits unrestricted use, distribution, and reproduction in any medium, provided you give appropriate credit to the original author(s) and the source, provide a link to the Creative Commons license, and indicate if changes were made.

\section{References}

Ayer, A. J. ([1936] 1952). Language, truth and logic. New York: Dover.

Beebe, J. R. (forthcoming) The empirical study of folk metaethics. Etyka, 50, 11-28.

Bennett, M. R., \& Hacker, P. M. (2003). Philosophical foundations of neuroscience. Oxford: Blackwell. Blackburn, S. (2000). Ruling passions: A theory of practical reasoning. Oxford: Oxford University Press. Blackburn, S. (2006). Antirealist expressivism and quasi-realism. In D. Copp (Ed.), The Oxford handbook of ethical theory (pp. 146-162). Oxford: Oxford University Press.

Boyd, R. (1988). How to be a moral realist. In G. Sayre-McCord (Ed.), Essays on moral realism (pp. 181-228). Ithaca: Cornell University Press. 
Brax, D. (2009). Neurometaethics. Unpublished Manuscript. http://david.brax.nu/wp-content/uploads/ 2009/09/Neurometaethics.pdf [2016-03-22].

Brink, D. O. (1989). Moral realism and the foundations of ethics. New York: Cambridge University Press.

Bruni, T. (2011). Neuroscience and moral reliability. AJOB Neuroscience, 2(2), 15-17.

Casebeer, W. (2003). Natural ethical facts: Evolution, connectionism, and moral cognition. Cambridge: MIT Press.

Copp, D. (2003). Why naturalism? Ethical Theory and Moral Practice, 6(2), 179-200.

Copp, D. (2004). Moral naturalism and three grades of normativity. In P. Schaber (Ed.), Normativity and naturalism (pp. 7-45). Frankfurt: Ontos-Verlag.

Cullen, S. (2010). Survey-driven romanticism. Review of Philosophy and Psychology, 1(2), 275-296.

Daniels, N. (1979). Wide reflective equilibrium and theory acceptance in ethics. Journal of Philosophy, 76(5), 256-82.

Devitt, M. (1991a). Realism and truth. Princeton: Princeton University Press.

Devitt, M. (1991b). Aberrations of the realism debate. Philosophical Studies, 61(1-2), 43-63.

Devitt, M. (2002). Moral realism: A naturalistic perspective. Croatian Journal of Philosophy, 2(1), 1-15.

Doris, J. M., \& Plakias, A. A. (2008). How to argue about disagreement: Evaluative diversity and moral realism. In W. Sinnott-Armstrong (Ed.), Moral psychology, vol. 2: The cognitive science of moralityintuition and diversity (pp. 303-331). Cambridge: MIT Press.

Dworkin, R. (1996). Objectivity and truth: You'd better believe it. Philosophy and Public Affairs, 25(2), 87-139.

Dworkin, R. (2011). Justice for Hedgehogs. Cambridge, MA: Harvard University Press.

Enoch, D. (2009). How is moral disagreement a problem for realism? Journal of Ethics, 13(1), 15-50.

Finlay, S. (2008). The error in the error theory. Australasian Journal of Philosophy, 86(3), 347-369.

Firth, R. (1952). Ethical absolutism and the ideal observer. Philosophy and Phenomenological Research, 12(3), 317-345.

FitzPatrick, W. J. (2014). Morality and evolutionary biology. In E. N. Zalta (Ed.), The stanford encyclopedia of philosophy. http://plato.stanford.edu/entries/moral-relativism/ [2014-09-12].

FitzPatrick, W. J. (2015). Debunking evolutionary debunking of ethical realism. Philosophical Studies, 172(4), 883-904.

Foot, P. (1972). Morality as a system of hypothetical imperatives. Philosophical Review, 81(3), 305-316.

Foot, P. (1978). Introduction. In P. Foot (Ed.), Virtues and vices and other essays in moral philosophy. Berkeley and Los Angeles: University of California Press. xi-xiv.

Fraser, B., \& Hauser, M. (2010). The Argument from disagreement and the role of cross-cultural empirical data. Mind and Language, 25(5), 541-560.

Geach, P. (1965). Assertion. Philosophical Review, 74(4), 449-465.

Gibbard, A. (1990). Wise choices, apt feelings: A theory of normative judgement. Cambridge, MA: Harvard University Press.

Gill, M. B. (2009). Indeterminacy and variability in meta-ethics. Philosophical Studies, 145(2), $215-234$.

Goldman, A. (1993). Ethics and cognitive science. Ethics, 103(2), 337-360.

Goodwin, G. P., \& Darley, J. M. (2008). The psychology of meta-ethics: Exploring objectivism. Cognition, 106(3), 1339-1366.

Gowans, C. W. (2000). Introduction: Debates about moral disagreements. In C. W. Gowans (Ed.), Moral disagreements: Classic and contemporary readings (pp. 1-44). London: Routledge.

Greene, J. D., Morelli, S. A., Lowenberg, K., Nystrom, L. E., \& Cohen, J. D. (2008). Cognitive load selectively interferes with utilitarian moral judgment. Cognition, 107(3), 1144-1154.

Greene, J. D., Sommerville, B. R., Nystrom, L. E., Darley, J. M., \& Cohen, J. D. (2001). An fMRI investigation of emotional engagement in moral judgment. Science, 293(5537), 2105-2108.

Haidt, J., \& Joseph, C. M. (2007). The moral mind: How 5 sets of innate moral intuitions guide the development of many culture-specific virtues, and perhaps even modules. In P. Carruthers, S. Laurence, \& S. Stich (Eds.), The innate mind, vol. 3: Foundations and the future. New York: Oxford University Press.

Hare, R. M. (1963). Freedom and reason. Oxford: Oxford University Press.

Harman, G. (1996). Moral relativism. In G. Harman \& J. J. Thompson (Eds.), Moral relativism and moral objectivity (pp. 1-64). Cambridge, MA: Blackwell.

Horgan, T., \& Timmons, M. (2008). What does moral phenomenology tell us about moral objectivity? Social Philosophy and Policy, 25(1), 267-300. 
Horvath, J. (2010). How (not) to react to experimental philosophy. Philosophical Psychology, 23(4), 447480.

Huemer, M. (2005). Ethical intuitionism. Basingstoke: Palgrave MacMillan.

Hume, D. ([1740] 1978). A treatise of human nature. Oxford: Clarendon Press.

Jackson, F. (1998). From metaphysics to ethics: A defense of conceptual analysis. Oxford: Clarendon Press.

James, W. (1884). What is an emotion? Mind, 9, 188-205.

Jones, K. (2006). Metaethics and emotions research: A response to Prinz. Philosophical Explorations, 9(1), 45-53.

Joyce, R. (2001). The myth of morality. Cambridge: Cambridge University Press.

Joyce, R. (2007a). Moral anti-realism. In E. N. Zalta (Ed.), The stanford encyclopedia of philosophy. http:// plato.stanford.edu/entries/moral-anti-realism/ [2011-12-03].

Joyce, R. (2007b). The evolution of morality. Cambridge \& London: The MIT Press.

Joyce, R. (2008). What neuroscience can (and cannot) contribute to metaethics. In W. Sinnott-Armstrong (Ed.), Moral psychology vol. 3: The neuroscience of morality-emotion, brain disorders, and development (pp. 371-394). Cambridge: MIT Press.

Joyce, R. (2013). The many moral nativisms. In K. Sterelny, R. Joyce, B. Calcott, \& B. Fraser (Eds.), Cooperation and its evolution (pp. 549-572). Cambridge, MA: MIT Press.

Kant, I. ([1785] 1993). Grounding for the metaphysics of morals. Hackett: Indianapolis.

Kaspar, D. (2012). Intuitionism. London: Bloomsbury.

Kauppinen, A. (2007). The rise and fall of experimental philosophy. Philosophical Explorations, 10(2), 95-118.

Kauppinen, A. (2008a) Essays in philosophical moral psychology. University of Helsinki: Ph.D. Thesis.

Kauppinen, A. (2008b). Moral internalism and the brain. Social Theory and Practice, 34(1), 1-24.

Knobe, J., \& Nichols, S. (2007). An experimental philosophy manifesto. In J. Knobe \& S. Nichols (Eds.), Experimental philosophy (pp. 3-14). Oxford: Oxford University Press.

Kramer, M. H. (2009). Moral realism as a moral doctrine. Oxford: Wiley-Blackwell.

Kripke, S. (1980). Naming and necessity. Cambridge, MA: Harvard University Press.

Kumar, V. (forthcoming). The ethical significance of cognitive science. In S.-J. Leslie, \& S. Cullen (Eds.), Current controversies in cognitive science. New York: Routledge.

Laskowski, N., Finlay, S. (forthcoming). Conceptual analysis in metaethics. In T. McPherson \& D. Plunkett (Eds.), Routledge handbook of metaethics. New York: Routledge.

Levy, N. (2011). Response to open peer commentaries on "Neuroethics: A New Way of Doing Ethics". AJOB Neuroscience, 2(2), W1-W4.

Loeb, D. (1998). Moral realism and the argument from disagreement. Philosophical Studies, 90(3), 281303.

Loeb, D. (2007). The argument from moral experience. Ethical Theory and Moral Practice, 10(5), 469-484.

Loeb, D. (2008). Moral incoherentism: How to pull a metaphysical rabbit out of a semantic hat. In W. Sinnott-Armstrong (Ed.), Moral psychology, vol. 2: The cognitive science of morality-Intuition and diversity (pp. 355-386). Cambridge: MIT Press.

Ludwig, K. (forthcoming). Thought experiments and experimental philosophy. In M. Stuart \& J. Brown (Eds.), Routledge companion to thought experiments. New York: Routledge.

Machery, E. (2009). Doing without concepts. Oxford: Oxford University Press.

Machery, E., \& Mallon, R. (2010). Evolution of morality. In J. M. Doris (Ed.), The moral psychology handbook (pp. 3-46). Oxford: Oxford University Press.

Mackie, J. L. ([1977] 2011). Ethics: inventing right and wrong. London: Penguin.

May, J. (2014). Does disgust influence moral judgment? Australasian Journal of Philosophy, 92(1), 125141.

Meyers, C. D. (2013). Defending moral realism from empirical evidence of disagreement. Social Theory and Practice, 39(3), 373-396.

Miller, A. (2014). Realism. In E. N. Zalta (Ed.), The stanford encyclopedia of philosophy. http://plato. stanford.edu/entries/realism/ [2014-10-03].

Miller, C. B. (2009). The conditions of moral realism. Journal of Philosophical Research, 34, 123-155.

Moore, G. E. ([1903] 1993). Principia Ethica. Cambridge: Cambridge University Press.

Nadelhoffer, T., \& Nahmias, E. (2007). The past and future of experimental philosophy. Philosophical Explorations, 10(2), 123-149. 
Nussbaum, M. C. (2004). Emotions as judgments of value and importance. In R. C. Solomon (Ed.), Thinking about feeling: Contemporary philosophers on emotions (pp. 183-199). Oxford: Oxford University Press.

Pigden, C. R. (1989). Logic and the autonomy of ethics. Australasian Journal of Philosophy, 67(2), 127151.

Pigden, C. R. (2011). Hume on is and ought. Philosophy Now 83.

Pigden, C. R. (2012). Identifying goodness. Australasian Journal of Philosophy, 90(1), 93-109.

Pölzler, T. (2015). Moral judgements and emotions: A less intimate relationship than recently claimed. Journal of Theoretical and Philosophical Psychology, 35(3), 177-195.

Pölzler, T. (2016). Revisiting folk moral realism. Review of Philosophy \& Psychology.

Pölzler, T. (forthcoming a). Are moral judgements adaptations? Three reasons why it is so difficult to tell. South African Journal of Philosophy.

Pölzler, T. (forthcoming b). How to measure moral realism. Article under review.

Pölzler, T. (forthcoming c). Moral reality and the empirical sciences. Book manuscript under contract with Routledge.

Prinz, J. J. (2006). The emotional basis of moral judgements. Philosophical Explorations, 9(1), 29-43.

Prinz, J. J. (2007). The emotional construction of morals. Oxford: Oxford University Press.

Prinz, J. J. (2010). Constructive sentimentalism: Legal and political implications. http://www.mit.edu/ $\sim$ shaslang/mprg/PrinzCS.pdf.

Prinz, J. J. (2015). Naturalizing metaethics. In T. Metzinger \& J. M. Windt (Eds.), Open MIND (pp. 1-27). Frankfurt am Main: MIND Group.

Quinn, P. L. (2000). Divine command theory. In L. F. Hugh (Ed.), The blackwell guide to ethical theory (pp. 53-73). Oxford: Blackwell.

Rachels, J. (1993). Subjectivism. In P. Singer (Ed.), A companion to ethics (pp. 432-441). Oxford: Blackwell.

Railton, P. (1986). Moral realism. Philosophical Review, 95, 163-207.

Richards, R. J. (1986). A defense of evolutionary ethics. Biology and Philosophy, 1(3), 265-293.

Ridge, M. (2014). Morality and evolutionary biology. In E. N. Zalta (Ed.), The stanford encyclopedia of philosophy. http://plato.stanford.edu/archives/fall2014/entries/moral-non-naturalism/ [2015-09-12].

Ruse, M. (1998). Taking darwin seriously, a naturalistic approach to philosophy. New York: Prometheus Books.

Ruse, M., \& Wilson, E. O. (1986). Moral philosophy as applied science. Philosophy, 61(236), 173-192.

Russell, B. (1918). On scientific method in philosophy. Oxford: Oxford University Press.

Salwén, H. (2003). Hume's law: An essay on moral reasoning. Stockholm: Almqvist \& Wiksell International.

Sauer, H. (2012). Psychopaths and filthy desks: Are emotions necessary and sufficient for moral judgment? Ethical Theory and Moral Practice, 15(1), 95-115.

Sayre-McCord, G. (1988). The many moral realisms. In G. Sayre-McCord (Ed.), Essays on moral realism (pp. 1-26). Ithaca: Cornell University Press.

Sayre-McCord, G. (2008). Moral semantics and empirical enquiry. In W. Sinnott-Armstrong (Ed.), Moral psychology, vol. 2: The cognitive science of morality-Intuition and diversity (pp. 403-412). Cambridge: MIT Press.

Schafer, K. (2010). Evolution and normative scepticism. Australasian Journal of Philosophy, 88(3), 471488.

Shafer-Landau, R. (2003). Moral realism: A defense. Oxford: Oxford University Press.

Shafer-Landau, R. (2006). Ethics as philosophy: A defense of ethical nonnaturalism. In T. Horgan \& M. Timmons (Eds.), Metaethics after moore (pp. 209-232). New York: Oxford University Press.

Shafer-Landau, R. (2010). Truth and metaethics. Boston University Law Review, 90(2), 479-496.

Shafer-Landau, R. (2012). Evolutionary debunking, moral realism, and moral knowledge. Journal of Ethics and Social Philosophy, 7(1), 1-37.

Smith, M. (1994). The moral problem. Oxford: Blackwell.

Sosa, E. (2007). Experimental philosophy and philosophical intuition. Philosophical Studies, 132(1), 99_ 107.

Street, S. (2006). A Darwinian dilemma for realist theories of value. Philosophical Studies, 127(1), 109-166.

Sturgeon, N. L. (1984). Moral explanations. In D. Copp \& D. Zimmerman (Eds.), Morality, reason and truth (pp. 49-78). Totowa: Rowman \& Allanheld.

Sturgeon, N. L. (1986). Harman on moral explanation of natural facts. Southern Journal of Philosophy, 24(S1), 69-78.

Svavarsdóttir, S. (1999). Moral cognitivism and motivation. The Philosophical Review, 108(2), 161-219. 
Sytsma, J., \& Livengood, J. (2016). The theory and practice of experimental philosophy. Peterborough: Broadview Press.

Toulmin, S. E. (1971). The concept of "stages" in psychological development. In T. Mischel (Ed.), Cognitive development and epistemology (pp. 25-60). New York: Academic Press.

Tropman, E. (2008). Naturalism and the new moral intuitionism. Journal of Philosophical Research, 33, $163-184$.

Vavova, K. (2014). Debunking evolutionary debunking. In R. Shafer-Landau (Ed.), Oxford studies in metaethics (Vol. 9, pp. 76-101). Oxford: Oxford University Press.

Wright, J. C., Grandjean, P. T., \& McWhite, C. B. (2013). The meta-ethical grounding of our moral beliefs: Evidence for meta-ethical pluralism. Philosophical Psychology, 26(3), 336-361.

Wright, J. C., McWhite, C. B., \& Grandjean, P. T. (2014). The cognitive mechanisms of intolerance: Do our meta-ethical commitments matter? In Knobe, J., Lombrozo, T., \& Nichols, S. (Eds.), Oxford studies in experimental philosophy (Vol. 1, pp. 28-61). Oxford: Oxford University Press. 